\title{
The UN in the Cambodia conflict: UNTAC
}

\begin{abstract}
A $\mathrm{N}$ examination of the UN Transitional Authority in Cambodia (UNTAC $)^{1}$ should prove especially illuminating for our study in that this mission points to the growing willingness of the international community to involve the UN in intra-state governance. It helps us, in other words, to scrutinise more closely the relationship between the changing normative basis of UN peacekeeping and the UN's evolving role in world politics.

The literature on the UN's Cambodia experience has rightly pointed to the 'comprehensive' nature of the mission. What is less well understood is the normative meaning and implications of this comprehensiveness, which is what this chapter seeks to elucidate. Here we explore the local, regional and global interests that impacted on the development of the idea of UN peacekeeping and the way these interacted, and at least temporarily synthesised to form a seemingly coherent normative framework for UN action. What is particularly revealing about this framework is not only the fact that the UN was given unprecedented authority in the process, but also the emergence of a complex blend of normative objectives which were partly reflected in the functions UNTAC was expected to perform.
\end{abstract}

\section{Historical background}

Cambodia became a French colony in $1887 .{ }^{2}$ In 1945 Prince Sihanouk $^{3}$ proclaimed Cambodia's independence from France, but at the conclusion of World War II the Allied troops arriving in Cambodia restored French rule. Sihanouk pursued a diplomatic campaign to gain independence from France, in which he eventually succeeded. In the Geneva Conference of May-June 1954, Sihanouk's Royal Government was recognised as the sole legitimate political authority in Cambodia.

In March 1969, with the escalation of the Vietnam War, the United States 
started to bomb communist 'sanctuaries' in Cambodia. Within one year Lon Nol and Sirik Matak had staged a coup d'état which overthrew Sihanouk and instituted a pro-American republican regime to replace the monarchy. Meanwhile, the South Vietnamese Army and the Americans increased their raids into communist sanctuaries. These incursions finally gave rise to a fullscale US invasion in April 1970. In December 1970, largely because of domestic political concerns, the US Government brought the invasion to an end. ${ }^{4}$ Soon after, a civil war broke out between Lon Nol's forces and the Khmer Rouge, which the latter eventually won in April 1975. ${ }^{5}$

The Khmer Rouge regime, led by Pol Pot and named Democratic Kampuchea in early 1976, pursued a determined campaign to eradicate all internal opposition to its Maoist programme in Cambodia. ${ }^{6}$ The actual toll of the radical Khmer Rouge attempt to forcefully reconstruct Cambodia as a selfsufficient agricultural society, where there was no place for money, would be known only after the regime was overthrown. The number of deaths in excess of Cambodia's normal mortality rate for $1975-78$ is estimated to be one million. ${ }^{7}$

While the Khmer Rouge instigated several military clashes with Thailand (an ASEAN member), ${ }^{8}$ they practically waged war against Vietnam. Even though the deeper roots of the Khmer Rouge's hostility towards Vietnam lay in the historical animosity between the Khmer and Vietnamese, ${ }^{9}$ the more recent political cause of the conflict was their relationship with Sihanouk. In the early 1970s, the Khmer Rouge had tried to get rid of Sihanouk in order to establish their own rule in Cambodia. At first, North Vietnam seemed a natural ally for the Khmer Rouge, ${ }^{10}$ since both were trying to establish communist regimes in Indochina. As the Vietnam War intensified, however, North Vietnam needed Sihanouk who, after all, had previously allowed North Vietnamese forces to operate from Cambodia against the US and South Vietnamese forces. The Khmer Rouge's seizure of power coincided with the fall of the South Vietnam regime. As early as May 1975, Cambodia and Vietnam directed allegations against each other, and eventually, in December 1978, Vietnam invaded Cambodia. ${ }^{11}$

The invasion took place in the wider context of the intra-communist political tension between the Soviet Union and China. ${ }^{12}$ The Khmer Rouge were an ideological and strategic ally of China before, during and after their short-lived reign. Hanoi, however, was sceptical about Mao's 'Cultural Revolutionary' policies abroad and Beijing's rapprochement with the United States in the early 1970s. ${ }^{13}$ Vietnam's persecution of its ethnic Chinese minority and the territorial disputes between China and Vietnam were yet other reasons contributing to Hanoi's increasing alignment with Moscow. ${ }^{14}$ On 29 June 1978, Vietnam joined COMECON. The Treaty of Friendship and Cooperation of 3 November 1978 marked the consolidation of the Soviet-Vietnamese alliance. ${ }^{15}$ 
A pro-Vietnamese government was installed in Phnom Penh, and the establishment of the People's Republic of Kampuchea (PRK) was officially proclaimed on 10 January $1979 .{ }^{16}$ The West, China, and ASEAN ${ }^{17}$ responded by isolating the Phnom Penh Government diplomatically and economically. ${ }^{18}$ In June 1982, ASEAN's persistent efforts led to the formation in Kuala Lumpur of the Coalition Government of Democratic Kampuchea (CGDK), ${ }^{19}$ which comprised the three most important groups opposed to the Phnom Penh regime: royalists (FUNCINPEC), non-communist republicans (KPNLF) and the Khmer Rouge (PDK). The CGDK lacked internal coherence, as the three factions were able to maintain their formal togetherness largely due to their pragmatic considerations.

A more organised resistance to Phnom Penh was encouraged by the external sponsors of the three factions which received open Thai support as well as more discreet US and Chinese support. ${ }^{20}$ The formation of the CGDK was intended partly to prevent the UN from seating the new Phnom Penh regime at the General Assembly, ${ }^{21}$ and partly to demonstrate unity and mobilise international support against Vietnam. ${ }^{22}$ The occupant of the Cambodian seat, that is, the Khmer Rouge Government, was attracting increasingly severe criticism, especially from the western public, for its past 'genocidal' policies. ${ }^{23}$ In the 1980 s, the CGDK, acting as a government in exile, continued to occupy the Cambodian seat in the UN with the support of western and ASEAN governments.

\section{Peacekeeping in Cambodia: the evolution of an idea}

Although it is not easy to date the original call for active UN involvement in Cambodia, it can be stated with reasonable confidence that the UN became involved in the Cambodia conflict mainly through ASEAN's efforts. In June 1981, the International Conference on Kampuchea was convened by the General Assembly at ASEAN's initiative, and attended by 79 states. The refusal of Vietnam and the Soviet bloc to participate soon brought the Conference to a deadlock. Its only achievement was the establishment of an Ad Hoc Committee to undertake peacemaking efforts. ${ }^{24}$ Peacekeeping was not yet on the agenda. In 1982, the Secretary-General began to advocate a change of strategy to deal with the Cambodia problem, pressing for discussions to be held in a much smaller forum than the International Conference and limited to those local, regional and global powers directly affected. ${ }^{25}$

\section{Contemplating peacekeeping - mainly with Hanoi in mind}

Until the late 1980s, it was Sihanouk and ASEAN who were the primary advocates of active UN involvement in Cambodia. The main emphasis in these 
early calls for UN intervention was on Vietnamese withdrawal - an idea which found support in neither Phnom Penh nor Vietnam. As early as 1980, Sihanouk was open to international control of Cambodia. ${ }^{26} \mathrm{He}$ would remain one of the driving forces behind the idea of active UN involvement in Cambodia, which would in turn gain increasing ASEAN support on the international stage. In 1983 ASEAN introduced a plan, the so-called ASEAN Appeal, which specifically mentioned 'international supervision' in relation to Vietnamese troops in Cambodia. Neither Hanoi nor Phnom Penh welcomed the idea. Over the next three years ASEAN continued with its efforts to bring an end to the regional instability caused by Vietnam's moves. ${ }^{27}$

On 17 March 1986, in response to ASEAN calls, the CGDK offered a peace plan, which inter alia called for a UN observer group to supervise the withdrawal of Vietnamese troops and the ensuing cease-fire, and to monitor the conduct of free elections. Soviet moves in April 1987 to 'normalise' SinoSoviet relations represented the first breakthrough: the main backers of the Phnom Penh Government and the CGDK would eventually come closer to the idea of settlement. The proposal to deploy an observer group would be eventually accepted by Phnom Penh's new Prime Minister, Hun Sen. The idea of UN peacekeeping in Cambodia gained strength thereafter, with the period between 1987 and 1991 witnessing a number of formal and informal meetings between Cambodian and international parties. ${ }^{28}$

With his coalition partners and Beijing still hesitant to engage in negotiations with Phnom Penh, Sihanouk decided to act individually to establish a dialogue. On 2 December 1987, the first meeting between Sihanouk and Hun Sen took place in Paris. ${ }^{29}$ Sihanouk's independent initiative put pressure on his coalition partners as well as on China and ASEAN to reconsider their uncompromising stance vis-à-vis dialogue. ${ }^{30}$ By January 1988, Sihanouk was insisting on the necessity of a peacekeeping force rather than a mere observer mission as envisaged by Hun Sen. ${ }^{31}$

Indonesia, ASEAN's designated interlocutor on Cambodia, carried the process of negotiation one step further. During the first ever face-to-face meeting of the four Cambodian factions in Jakarta on 25-28 July 1988 (the first Jakarta Informal Meeting), the Phnom Penh Government rejected the idea of international peacekeeping. So did Vietnam, which for the first time had sent a delegation to multilateral negotiations on Cambodia. Phnom Penh and Hanoi were highly sceptical of the internationalisation of attempts to settle the dispute through the UN where there seemed no prospect of support for their cause.

\section{The idea gains credibility: neutralisation of both Hanoi and the Khmer Rouge}

All along, another obstacle in the path of finding a workable peacekeeping formula was the position of the Khmer Rouge who were well aware of the fact 
that the support extended to them by China and ASEAN (especially Thailand $)^{32}$ owed much to these actors' strategic interests. If these interests changed, the UN (that is to say, both the General Assembly and the Security Council) might easily turn against the Khmer Rouge. Reports and evidence documenting their atrocities were already in wide circulation in UN corridors. ${ }^{33}$ It was not until late 1988 that the Khmer Rouge gave their explicit support to Sihanouk's demand for international peacekeepers: ${ }^{34}$ 'An international peace-keeping force would be stationed throughout Cambodia to enforce the agreement. ${ }^{35}$ The assurances given by China that it would protect the interests of the Khmer Rouge, and more generally its strongly stated public position on the issue played a decisive role in this change of attitude. ${ }^{36}$

The three CGDK partners entered the second Jakarta Informal Meeting in relative harmony. According to the new Sihanouk proposal of 30 November 1988 , a substantial international peacekeeping force, capable of preventing election frauds, was necessary. The functions envisaged for the force were: first, to ensure that the Khmer Rouge would not monopolise power; secondly, to verify Vietnamese non-aggression and non-interference; and thirdly, to prevent a civil war in Cambodia. In order to accommodate Phnom Penh's and Hanoi's wishes, Sihanouk was now willing to try and 'neutralise' the Khmer Rouge, while taking care that such a strategy did not entail a return to civil war. 'Prevention of civil war' in this sense had to be part of the mandate of the proposed UN peacekeeping force. More importantly, the idea of UN peacekeeping gained credibility only after it was placed within a wider context. UN involvement was now sought not only against Vietnam but also against the Khmer Rouge. ${ }^{37}$

In effect, Sihanouk's new approach called for more than the UN's traditional peacekeeping role, that is, maintenance of international peace and security and prevention of foreign intervention. We have already seen that the Security Council had made 'prevention of civil war' part of the peacekeeping mandate in the Congo. The difference is that this time the demand to include this objective in the mandate came directly from one of the intra-state parties, and emerged out of a concern to accommodate the diverse interests of opposing actors. The more diverse interests and perceptions were taken into consideration, which was necessary for a peaceful settlement of the conflict, the wider became the role prescribed for the UN.

Sihanouk's attempt to work out an acceptable solution did not immediately lend itself to unanimous acceptance of a peacekeeping role for the UN. For Phnom Penh the very idea of international peacekeepers implied an infringement of Cambodia's sovereignty. The most that Phnom Penh was prepared to accept was a 600-strong mission, with its role limited to observation of the 'external' aspect of the conflict, that is, the Vietnamese withdrawal. On 5 April 1989, a joint declaration by Phnom Penh, Vietnam and Laos called 
for supervision by the International Control and Supervision Commission established under the 1954 Geneva Agreements. ${ }^{38}$ The proposed supervision would be supplemented by the chairman of the Jakarta Informal Meeting and a representative of the Secretary-General. Communist Indochina did not wish to assign a greater role to the UN, where the CGDK representative was still seated in the General Assembly, and where their only supporters seemed to be members of the Soviet bloc. ${ }^{39}$

Following the repeated failure of reconciliation attempts, a conference was organised at the initiative of the French Government in Paris in July 1989. In addition to the four Cambodian factions, the Permanent Five, the members of ASEAN, Vietnam and Laos (the other two Indochinese states), India and Canada (both former Control Commission states), Zimbabwe (acting chair of the NAM), Australia, Japan, and the Secretary-General all participated in the First Paris Conference on Cambodia. ${ }^{40}$ The most significant rule of the game at the Conference was set by two rivals, that is, Vietnam and China. On their insistence, the principle of unanimity was adopted when dealing with substantive issues. ${ }^{41}$ This arrangement effectively delivered the right of veto to the China-sponsored Khmer Rouge on the one hand, and the Vietnam-sponsored Phnom Penh Government on the other. This practical necessity would have two long-term normative implications.

First, the subsequent multilateral agreements and UN decisions on Cambodia would use rhetoric that attempted to reconcile the different interests and normative preferences of all parties. In concrete terms this meant that the language adopted would highlight the importance of both the inviolability of Cambodia's sovereignty and respect for human rights. China's normative priority was clearly the former, with an emphasis on removing Vietnamese dominance in Cambodia's internal affairs. Vietnam, on the other hand, continually stressed its concern that the previous Khmer Rouge regime, which had perpetrated gross human rights abuses, should not be allowed to recapture power in Cambodia.

Secondly, the Conference would give the first signs of enhanced UN authority in dealing with the Cambodian conflict. De Cuéllar emphatically underlines in his memoirs that the UN was a full participant at the Paris Conference, even though he signed the final document only as a witness. Full participation meant that the UN delegation was given the right to speak and to vote just as the national delegations were. It also meant that the UN had the right to veto any proposals, since all decisions were to be reached by unanimity. ${ }^{42}$ In other words, the UN was accorded the status of an autonomous actor, which could pursue its independent agenda in relation to the settlement of the conflict.

The Conference organised itself into five working groups, each concerned with a different aspect of the conflict. Perhaps the most important of these was 
the fourth group - the so-called 'Ad Hoc Group' which dealt with the issues of national reconciliation and an interim authority in Cambodia. It was largely because of the disagreements within this group that the Conference came to a deadlock and was eventually suspended. One observer attributed its failure to Phnom Penh's refusal to share power in the interim period which would precede the proposed elections. ${ }^{43}$ One of the most contested issues was partial delegation of Cambodian sovereignty to a provisional polity of which the UN would be an integral part. Although the Conference failed to break the deadlock, there was general consensus at its close that some kind of International Control Mechanism should supervise the internal aspects of a future Cambodian settlement, and that, regardless of its precise mandate, the 'mechanism' should be a UN operation. ${ }^{44}$ On 26 September 1989, Vietnam formally withdrew from Cambodia. ${ }^{45}$

\section{Lead-up to UN 'protectorate': \\ from the Australian Plan to the Paris Agreement}

November 1989 proved a milestone in the international handling of the Cambodia situation. First, the General Assembly adopted a resolution calling for 'the creation of an interim administering authority'. ${ }^{46}$ Then, on 24 November 1989, a more radical settlement proposal was put forward, which proved nevertheless more acceptable from Phnom Penh's viewpoint. Gareth Evans, the Australian Foreign Minister, gave a speech to the Australian Senate where he summarised the main points of a plan to resolve the Cambodia conflict. He envisaged a role for the UN, which went far beyond mediation and supervision. ${ }^{47}$ In effect, Evans proposed a UN trusteeship in Cambodia. His formulation was not anti-Phnom Penh in tone. Two weeks later, Hun Sen expressed his readiness to 'consider' the Evans plan.

The third of the Jakarta meetings on Cambodia, held on 26-28 February 1990, put the Australian proposal on its agenda, by which time Australia had already turned Evans' proposal into a collection of ten separate papers laying down more detailed plans. ${ }^{48}$ The plan, which introduced the idea that the settlement of the Cambodia problem would require a comprehensive package, sought to designate a temporary form of political authority in Cambodia. ${ }^{49}$ Chinese and US insistence on comprehensiveness was already well established.

From the outset, the Australian plan was sensitive to the issue of the UN's image. It gave the impression that the UN's authority vis-à-vis Cambodia would be limited. It stated clearly that no agreement on a comprehensive settlement could decide between the competing claims as to which party constituted the legitimate government of Cambodia, or determine what would be Cambodia's constitutional order and social and political system. ${ }^{50}$ 
Adherence to transitional arrangements would not involve any acknowledgment that the previously asserted rights of any party were either legitimate or illegitimate, accepted or rejected. ${ }^{51}$ As a logical corollary of this, the UN could not be expected or allowed to make judgements as to which of the parties would be the legitimate office holder. The plan proposed instead the establishment of a Supreme National Council (SNC) to be formed by the four factions. All government authority would be vested in this Council. Taken at face value, then, a strict 'neutrality' was envisaged for the UN, reminiscent of the Cold War period.

A closer reading of the plan, however, revealed that the UN would be endowed with unprecedented political authority with far-reaching normative implications for governance. The SNC was expected to devolve its legislative, executive, and judicial authority to the Secretary-General, who would be authorised by the Security Council to accept and exercise that authority. The Secretary-General would be able to delegate, and resume, this authority to such officials or external agencies as he deemed appropriate. ${ }^{52}$ This was in effect a call for the empowerment of the UN (in the person of its SecretaryGeneral) to exercise greater authority vis-à-vis the Cambodian conflict. Among other things, it reflected a concern to accommodate the expectations, perceptions and interests of two key allies, Phnom Penh and Hanoi.

For years, the Phnom Penh regime had not been seated in the UN. ASEAN-sponsored General Assembly resolutions had associated the Phnom Penh regime with the Vietnamese invasion, and steadfastly refused to confer official legitimacy to it. Vietnam, on the other hand, was widely considered an aggressor. Security Council action against Hanoi and Phnom Penh had been averted only by dedicated Soviet efforts. ${ }^{53}$ As a consequence, Hanoi and Phnom Penh, without whose cooperation there could be no peaceful resolution, considered the UN's deliberative bodies as unfriendly, if not inimical. If, however, the UN based its actions in Cambodia on the authority of the Secretary-General, and not the General Assembly, this difficulty might be surmounted. ${ }^{54}$ By making the Secretary-General the focal point of UN involvement, Australia had effectively removed an important barrier to settlement: Hanoi's and Phnom Penh's distrust of the organisation.

The proposed direct UN involvement in the Cambodian civil administration was in practice designed to sidestep the issue of power-sharing which had impeded progress at the Paris Conference. Temporary transfer of authority to the UN would enable the interested parties not to enter dangerous territory during negotiations, that is, the issue of which faction would get what share in Cambodia's temporary governance. This was a particularly delicate question, since it was the key to 'legitimate' re-entry of the Khmer Rouge into Cambodia. It might also have implied that Phnom Penh was expected to give up its relative advantage in bargaining, namely dismantling 
the country's administrative structures which were largely under Phnom Penh's control.

Soon it became clear that the envisaged interim administration would in fact serve more the interests of the Phnom Penh Government than of their major rival, the Khmer Rouge. In response to mounting domestic accusations that his plan accommodated the genocidal Khmer Rouge, Evans would argue that the plan in fact sought to constrain the role of the Khmer Rouge during the transitional arrangements. ${ }^{55}$ Accordingly, the plan envisaged that the 'existing' civil administration in Cambodia would, as part of the search for an arrangement acceptable to Phnom Penh, be permitted to continue with its day-to-day activities. ${ }^{56}$ Despite the weakening of its position, Phnom Penh's administrative apparatus would in effect remain largely in place. Phnom Penh would in these circumstances be willing to compromise, because such an arrangement would still give it the upper hand. Its opposition to the idea of extensive UN involvement in Cambodia gradually diminished.

Despite a number of disagreements between the factions, the third Jakarta meeting did result in the signing of the first ever joint communiqué by the four factions. Given the sympathetic response of the Permanent Five to the Australian Plan, ${ }^{57}$ the factions came to accept the idea of a UN presence in Cambodia for the interim period before the elections. They also agreed to the establishment of a Supreme National Council which would embody Cambodia's 'national sovereignty and unity' for the period in question. As one might expect, both points were surrounded by ambiguities. First, the UN presence would be 'at appropriate levels' - a phrase clearly open to interpretation. For his part, Hun Sen stressed the limits of Phnom Penh's latest concessions to the emerging international support for an extensive UN role in Cambodia. In his view the UN should not go beyond organising elections; it could not be allowed to 'manage, control, or govern Cambodia'. Secondly, the formula by which the SNC should be organised was not specified. Phnom Penh opposed the dismantling of the existing governmental structure as suggested by Sihanouk. ${ }^{58}$

\section{Reconciling geostrategic interests: the Permanent Five as a conjunctural 'bloc'}

On 15-16 January 1990, on the initiative of the United States, the deputy foreign ministers of the Permanent Five held in Paris their first meeting on Cambodia. From that moment on, the representatives of the Permanent Five gathered on a monthly basis. The discourse of the UNTAC period was largely set during these meetings which continuously referred to 'comprehensive political settlement', 'cessation of outside military assistance', 'enhanced UN role', 'effective presence', and 'neutral political environment'. A course of action began to be specified by the Permanent Five in the light of the ideas, 
positions and plans already in circulation, and a summary of conclusions was issued. ${ }^{59}$

Until their adoption of the so-called Framework Document on 28 August $1990,{ }^{60}$ the Permanent Five held several meetings. ${ }^{61}$ During this negotiation process, it was China, more than any other actor, which complicated the issue for the other permanent members. China insisted, first, that the Phnom Penh Government be totally dismantled prior to UN deployment; and secondly, that the Khmer Rouge not be excluded from the process. The first point was resisted mainly by the Soviet Union, Phnom Penh's main supporter, while the second point continued to provoke opposition from the other three powers, whose publics had long associated the Khmer Rouge with genocidal practices. A political stalemate seemingly ensued. The Permanent Five meetings had not succeeded in reconciling the positions of the relevant parties.

In March 1990, in what was perhaps a landmark move, the Permanent Five issued a call to the Cambodian factions to delegate Cambodian national sovereignty to the proposed UN mission during the transitional period. The Permanent Five referred to a UN body whose system and procedures would be 'absolutely impartial'. All Cambodian participants would have the same rights, freedoms and opportunities in the election process. Once this stance was adopted, the supporters of all four factions eventually agreed to make the necessary compromises. China gradually withdrew its insistence on up-front dismantling of the Phnom Penh administrative structures $;{ }^{62}$ the Soviet Union dropped its reference to Khmer Rouge genocide; and the three western powers simply endorsed the obvious reality: the two rival communist Cambodian factions would have a say over Cambodia's future.

The Permanent Members came to agree in principle that the UN's role in the resolution of the Cambodian problem should be substantially 'enhanced'. ${ }^{63}$ According to their joint statement the complete withdrawal of foreign forces had to be 'verified by the UN'; ${ }^{64}$ free and fair elections had to be conducted under 'direct UN administration'; ${ }^{65}$ an 'effective' UN presence would be required during the transition period in order to assure 'internal security'; 66 the scale of the UN operation should be 'consistent with the successful implementation' of a Cambodian settlement; ${ }^{67}$ and a Special Representative should be appointed to supervise UN activities. ${ }^{68}$ The Secretary-General would comment:

How far would such internal involvement extend and how would it relate to the sovereignty of the Supreme National Council as described in the principles defined by the Five? ... For more than four decades, the Permanent Members had been reluctant to give the United Nations any independent authority at all. Now they seemed prepared to have it administer a whole country, a task that was, in my view, inappropriate and beyond its capacity. ${ }^{69}$ 
Reconciliation of the Permanent Five's interests in the Cambodian context had such enormous normative implications for the UN's future that the Secretary-General felt obliged to express concern over possible ramifications. The UN had never taken direct responsibility for the maintenance of law and order within a sovereign state. Neither had it been directly responsible for the conduct of elections in an independent country. These functions meant that the UN would inevitably become involved in aspects of Cambodia's domestic affairs, ${ }^{70}$ putting into question the UN's adherence to the principle of nonintervention.

The Secretariat's concerns notwithstanding, any interim solution other than a UN administration seemed unfeasible to the Permanent Five. Any other mechanism would serve the interests of one or another permanent member. Whether the UN was actually capable of performing such extensive functions as foreshadowed by the Permanent Five remained a point of controversy. Normatively speaking, nevertheless, the UN was assigned a role that would set a precedent for years to come.

The authority prescribed for the Secretary-General in the Australian Plan was taken one step further by the Permanent Five. The Secretariat proposed that in the event of the SNC not being able to reach consensus, the Special Representative of the Secretary-General should be entitled to make a final decision, taking fully into account views expressed in the Council. This provision gave the Special Representative, and through him the Secretary-General, 'supreme power if he chose to use it'. ${ }^{71}$ The UN's authority in relation to the Cambodian conflict was now fully endorsed by the Permanent Five. On 26 November 1990 came their 'draft comprehensive political settlement' (the Draft Agreement), ${ }^{72}$ which was developed directly from the Framework Document.

\section{Reconciling regional interests}

As the Permanent Five engaged in extensive consultations on Cambodia, a parallel series of meetings took place between the four factions and interested states. In Tokyo, a meeting organised by Thailand and Japan to discuss Sihanouk's nine-point proposal of 9 April 1990, reduced the gap between the positions adopted by FUNCINPEC, the KPNLF and Phnom Penh. ${ }^{73}$ To be able to exert a degree of pressure on Phnom Penh, the two coalition partners of the Khmer Rouge were now willing to act at its expense. In a sense, Sihanouk and Son Sann, acting on behalf of FUNCINPEC and the KPNLF respectively, clearly signalled at the Tokyo meeting that they valued a compromise with Phnom Penh more than their strategic alliance with the Khmer Rouge. The Tokyo meeting did not address the issue of the proposed UN role in Cambodia, but concentrated instead on the establishment of the SNC. By the end of the 
meeting an agreement on the composition of the Council had begun to emerge.

The factions held another meeting in Jakarta on 9-10 September 1990, and finally established the 12-member SNC, ${ }^{74}$ even though the question of the Council's presidency remained a bone of serious contention. Throughout the following year, the SNC held various meetings, ${ }^{75}$ with the discussions focusing on power-sharing arrangements among the factions. Perhaps the most important achievement of this phase of the negotiation process was the decision, taken after prolonged debate at the Beijing meeting of 16-17 July 1991, to endorse Sihanouk as chairman of the SNC. However, the serious disagreement between Phnom Penh and the CGDK on the UN's role continued. Fearful that the UN might engage in an administrative takeover of Cambodia, the former still portrayed an extensive UN role as a violation of Cambodia's sovereignty. Demobilisation of Cambodian armed forces by the UN was considered unacceptable. Phnom Penh was at best prepared to countenance a small UN presence with a limited range of monitoring functions. ${ }^{76}$

Despite the obstacles to a detailed agreement between the factions, in autumn 1991 the political atmosphere was conducive to a second attempt at resolving the conflict. At the very least, there was now sufficient consensus among the factions' international backers, which could be used as leverage. At the invitation of the French Government, the Second Paris Conference convened on 21 October 1991. Legally, Cambodia was now represented by a single body, the SNC, although in practice all four factions were invited. The participants of the First Paris Conference were again all present. ${ }^{77}$ The Conference resulted in the signing of four separate documents, which would provide the basis of an active UN presence in Cambodia: the Final Act; the Agreement on Political Settlement (with its 5 annexes); the Agreement on Cambodia's Sovereignty; and finally the Declaration on Rehabilitation. ${ }^{78}$ Through these accords, the Cambodian factions formally invited the Security Council to establish a UN mission in their country.

The provisions of the Agreement signalled the actors' determination to solve the critical issue of consent once and for all. Throughout the four-year negotiation process, Phnom Penh had made it amply clear that it would not accept a UN 'takeover' of its governmental privileges. The obstacle associated with the Khmer Rouge position had been handled largely through Beijing's leverage and Sihanouk's appeasement. Both parties could at any moment withdraw their consent from the peace process. ${ }^{79}$ The Agreement clearly indicated that the signature by the SNC members would commit all Cambodian parties and armed forces to the provisions of the Agreement. ${ }^{80}$ It underlined that the SNC thereby delegated to the UN all powers necessary to ensure the implementation of the Agreement. ${ }^{81}$ As a consequence, the authoritative interpretation of the Agreement, that is, judgements as to its content, would belong to the UN. 
Considered in the light of the Congo and Cyprus experiences, where the parties to the conflict remained entitled to their own interpretation of the UN's mandate, this was a substantial assertion of the UN's normative authority. Uch Kiman, the Cambodian Secretary of State for Foreign Affairs, would later comment:

The first and foremost feature of UNTAC was that it was a serious infringement on Cambodian sovereignty. This was probably the most bitter pill which we all had to swallow. For the sake of peace and national reconciliation, we accepted that the UN more or less run the local government and allowed it to organize general elections in a member state. We had to accept the 'Akashi Protectorate' and referred to the position held by H.E. Yasushi Akashi ... as that of a 'Viceroy'. 82

The Accords placed all administrative agencies, bodies and offices in the fields of foreign affairs, national defence, finance, public security and information under the direct control of UNTAC, and further empowered the UN to issue directives which would be binding on all Cambodian parties. ${ }^{83}$ This aspect of the settlement package indicates a substantial enhancement of the UN's authority and functions, and stands in stark contrast to the Congo and Cyprus cases. In the Cambodian context, the UN was to all intents and purposes given a temporary trusteeship role in a legally sovereign country.

\section{The mandate: sovereignty and human rights hand in hand}

In contrast to the Congo and Cyprus missions, UNTAC's formal mandate took shape outside of the UN. It was specified in the Paris Accords rather than in a UN resolution. UNTAC was authorised by the Security Council mainly to implement 'the mandate envisaged in the agreements on a comprehensive political settlement to the Cambodia conflict' ${ }^{84}$ Once established, the future of the mission was almost exclusively determined by the Security Council in close interaction with the Secretary-General. ${ }^{85}$ The role of the General Assembly in defining UNTAC's mandate or shaping its actions was minimal, and at best informal.

The extensive role prescribed for UNTAC was closely connected with both state-centric and human-centric principles:

The States participating in the Paris Conference on Cambodia ...

In order to maintain, preserve and defend the sovereignty, independence, territorial integrity and inviolability, neutrality and national unity of Cambodia ...

Recognizing that Cambodia's tragic recent history requires special measures to assure protection of human rights, and the non-return to the policies and practices of the past,

Have agreed ... ${ }^{86}$

The incorporation of state-centric and human-centric principles to UNTAC's 
mandate was a way of reconciling the contradictory interests of the relevant players and resulted from a decade-long process of negotiation. Several factors contributed to UNTAC's assumption of human rights and humanitarian responsibilities. Although the influence of public pressure, mobilised especially by western media and civil society organisations, is not negligible, two other factors were arguably more decisive in shaping the UN's normative preferences. First, in the aftermath of the Vietnamese intervention three key non-western players (Moscow, Hanoi and Phnom Penh) consistently appealed to the human rights discourse in pursuit of their strategy against the Khmer Rouge whose principal backer was Beijing. Secondly, the selective insistence by western governments, in particular the United States, on human rights issues made possible that a human-centric discourse be adopted as a way of reconciling the different interests of the direct and indirect parties to the conflict.

\section{Influence of non-governmental actors}

Following the regime change in Cambodia in 1978, western public opinion became increasingly critical of the atrocities committed by the Khmer Rouge. Calls were made with increasing frequency and intensity by media organs and NGOs to punish those guilty of massacres on the one hand, and to alleviate the ensuing humanitarian situation on the other. These calls attracted the attention of western governments even before the fall of the Khmer Rouge regime. A policy paper, prepared by the US Department of State, mentioned by name such organisations as Amnesty International and the International Commission of Jurists, adding that the Department would be prepared to consider what useful role it could play, should any effort be undertaken by any organisation in relation to the human rights situation in Cambodia. ${ }^{87}$

On 3 March 1978, when the British Under-Secretary of State addressed the UN Commission of Human Rights, he made references to gross human rights violations reported by several informed organisations and media organs, including Amnesty International, The Times, the Guardian, and Le Monde. ${ }^{88}$ In France, mounting criticism from the ranks of the parliament and from intellectual circles forced the government to clarify its policy in regard to Pol Pot's atrocities. The government had to publicly account for its failure to vote at the General Assembly in favour of the new Phnom Penh regime. ${ }^{89}$

NGO efforts to mobilise international support in order to correct Cambodia's past injustices, to provide humanitarian assistance, and to facilitate socio-economic development persisted before and after the UNTAC period. ${ }^{90}$ Systematic NGO involvement in the Cambodian crisis went through three phases until 1995: 'emergency' (1979-82), 'isolation' (1982-87), and 'transition and liberalisation' (1988-95). ${ }^{91}$ 
From the early 1980s, NGOs formed several consortia in Cambodia. The Oxfam-NGO Consortium, Agricultural Relief and Rehabilitation in Kampuchea (ARRK) and Partnership for Development in Kampuchea (PADEK) are among notable examples. ${ }^{92}$ Perhaps the most important step in NGO involvement was the establishment of the Cooperation Committee for Cambodia (CCC) in April 1990. The membership of the CCC would increase from 25 to 47 in four months. By 1992, more than 70 international NGOs were active in Cambodia. ${ }^{93}$

Field activities of non-governmental actors were also complemented by advocacy campaigns. In 1986, 20 leading NGOs from Australia, Europe, Japan, and the United States, ${ }^{94}$ for instance, formed an ad hoc coalition to raise the profile of the Cambodian issue worldwide. ${ }^{95}$ They were categorical in their assessment of what was needed for Cambodia's recovery: first, a guarantee that the Khmer Rouge would not return to power; secondly, peace and stability to enable the people to pursue a normal social and economic life; thirdly, material aid, both for emergency use and for reconstruction; and finally, a greater degree of independence and self-determination. ${ }^{96}$ Although it is not easy to suggest a causal link, it is safe to assume that such advocacy, greatly amplified by widespread media coverage, exerted indirect but substantial influence on the definition of UNTAC's normative basis. All four points would be addressed by the Paris Accords as well as by the Secretary-General's implementation plan.

\section{Human rights rhetoric by Moscow, Hanoi and Phnom Penh}

All along, a key bone of contention between the positions of Phnom Penh and the CGDK was the status of the Khmer Rouge. Phnom Penh as well as Vietnam insisted on labelling past Khmer Rouge actions as 'genocide'. The Pol Pot 'clique' could not be allowed to participate in Cambodian elections. By contrast, Sihanouk considered the role of the Khmer Rouge as the main stumbling block to Vietnamese colonisation of Cambodia, and argued that Hanoi simply wanted to eliminate this main obstacle to its expansionist plans. For their part, the Vietnamese and the Phnom Penh governments adopted a clear line of normative argument, according to which there had been no Vietnamese intervention in Cambodia's domestic affairs. What had occurred in Cambodia was the legitimate overthrow of an illegitimate government which had grossly and indiscriminately violated the human rights of its people - a sequence of events described as the 'logical development of the mass uprising of the entire Kampuchean people'. ${ }^{97}$

In the days before the Khmer Rouge turned to Beijing for support, the Soviet Union had categorically opposed a draft resolution at the UN Commission of Human Rights, calling for a 'thorough study of the human rights situation in 
Democratic Kampuchea'. It had accused the United States and its allies of presenting biased information using the pretext of protecting human rights simply to undermine the prestige of the socialist states. ${ }^{98}$ In the aftermath of the Vietnamese invasion, the Soviet position underwent strategic change. ${ }^{99}$ Throughout the 1980s, it would argue, first, that the change of regime in Phnom Penh had taken place as a result not of Vietnamese intervention, but of civil war, and secondly, that the Khmer Rouge regime was guilty of genocide.

Central to Moscow's, Hanoi's and Phnom Penh's propaganda campaign was the emphasis on the 'genocide' committed by the Khmer Rouge. In the Secretary-General's opinion, the use of the word 'genocide' and 'genocidal' would raise the question of applicability of the Convention against Genocide. Neither the Khmer Rouge, nor their coalition partners in the CGDK, nor China would be willing to agree on a Cambodian settlement under these terms. An alternative phrase was, therefore, embraced in reference to the Khmer Rouge legacy: 'universally condemned policies and practices of the recent past'. ${ }^{100}$ This phrase would be essentially retained in all subsequent discussions, and would find its way into the Paris Accords as well as subsequent UN resolutions on Cambodia. ${ }^{101}$

Although the Soviet Union began to contradict its earlier position by attacking the Pol Pot regime on human rights grounds, it remained consistent in its most characteristic normative preference, that is, the principle of nonintervention in domestic affairs. The Soviet Union was at the time itself the target of severe criticism over its human rights record. In a Security Council debate on the Vietnamese intervention, the Soviet Union held that the Khmer Rouge were overthrown by the Cambodian people through an internal revolution. There was therefore no need for the Security Council to take action, given that the situation involved 'a purely internal question of concern only to the people of that country'. ${ }^{102}$ By implication at least, the view of the Soviet delegation was that the Security Council would have had a responsibility to act, had it been a case of external aggression. A civil war, however, was beyond the scope of Security Council action, even if it resulted in gross human rights violations. Significantly, this highly state-centric view would change on the eve of UNTAC's authorisation. By endorsing the Framewok Document the Soviet Union accepted the argument that the adoption by the UN of 'all appropriate measures'103 could be justified either on the grounds that Cambodia's independence, sovereignty and territorial integrity were under threat or as a response to human rights violations. ${ }^{104}$

\section{Selective western insistence on human rights}

Persistent use of human rights discourse by western governments, albeit selectively, was yet another factor contributing to the definition of UNTAC's 
objectives. These governments' unwillingness, supported by ASEAN and China, to deny the Khmer Rouge international recognition was essentially a strategic choice, which inevitably prompted accusations of hypocrisy from voices influential in shaping world opinion and from the Soviet bloc. President Carter, it should be remembered, had denounced the Khmer Rouge Government as the 'worst violator' of human rights, followed by a unanimous vote by the US House of Representatives to condemn the Cambodian regime. ${ }^{105}$ The United States nevertheless voted in favour of seating the Khmer Rouge representative in the General Assembly, ${ }^{106}$ and throughout the following decade, Phnom Penh would continue to be subjected to economic and diplomatic isolation, thereby exacerbating Cambodia's humanitarian catastrophe.

Once the major actors were determined to 'settle', if not end, the Cambodian conflict, the rhetorical western commitment to human rights proved useful, since it converged with Soviet and Vietnamese insistence on the importance of preventing Cambodia's return to its genocidal past. China, then, posed the main obstacle to the incorporation of human-centric normative discourse into the UN's job description. As early as May 1987 Deng Xiao Ping had provided the Secretary-General with an authoritative statement of the Chinese position on Cambodia. ${ }^{107}$ It was true, Deng held, that 'Pol Pot made many mistakes, by no means small ones', but the Vietnamese invasion was a more serious mistake - 'by a long way'. He stressed that the internal mistakes of individuals could not compare with foreign invasion; that the principle of non-intervention had worldwide application; and that the Cambodian people should be allowed to solve their own problem themselves.

With growing international criticism following the events at Tienanmen Square, however, China's leverage was weakened, which may help to explain the softening of its position. In any case, China had as early as 1987 signalled a possible way of formulating a settlement. Although Deng insisted that the Khmer Rouge could not be excluded from the peace process, he suggested that China would not support a government headed by Pol Pot, only one by Sihanouk. ${ }^{108}$ While exclusion of the Pol Pot group from the settlement would implicitly address other actors' human rights concerns, it would at the same time keep the issue of human rights in low profile.

Eventually, after a strong and successful advocacy, the United States would manage to decorate the Draft Agreement of the Permanent Five with ample references to human rights. Accordingly, the Agreement went beyond the Framework Document in that it required Cambodia 'to support the right of all Cambodian citizens to undertake activities which would promote and protect human rights and fundamental freedoms'. In addition, whereas the Framework Document had called merely for 'necessary measures' to be taken in order to observe human rights and prevent a return to the 'policies and 
practices of the past', ${ }^{109}$ the Draft Agreement replaced the vaguer phrase 'necessary measures' with the stronger phrase 'effective measures'. ${ }^{110}$

The rhetorical language used pointed to Washington's capacity to translate its political agenda into accepted normative discourse. Because of determined Chinese insistence on full Khmer Rouge participation in the Cambodian settlement, exclusion of the faction from the process had not been possible. A second best objective from the US perspective was to minimise the Khmer Rouge influence, which was seen as antithetical to long-term US interests in Indochina. In the aftermath of Vietnam's withdrawal from Cambodia, the Khmer Rouge were no longer seen as serving American interests. Containment of the Khmer Rouge had become necessary, because the Soviet Union might otherwise terminate its continuing support for the burgeoning peace process. Moreover, it was not easy to include in the 'peace' process a faction which had been condemned for years for its genocidal practices. The United States could no longer afford to ignore the strong anti-Khmer Rouge sentiment in western public opinion.

The Final Act announced that the Paris Accords represented essentially an elaboration of the Permanent Five's Framework Document. ${ }^{111}$ As for the overall conceptualisation, there was practically no difference between the Draft Agreements and the Accords. The former's human rights clauses were fully contained in the latter. The Agreement on Political Settlement recognised 'that Cambodia's tragic recent history requires special measures to assure protection of human rights, and the non-return to the policies and practices of the past'. In addition, Part III of the same instrument was specifically devoted to human rights.

The Permanent Five joint statement of 16 January 1990 had contemplated that a Supreme National Council might be the repository of Cambodian sovereignty during the transition process. ${ }^{112}$ Provision 3 stated that the goal was self-determination for the Cambodian people through free, fair and democratic elections, with provisions 7 and 12 specifying to some extent the meaning of 'free and fair': the transition process should not be dominated by any of the Cambodian factions, and elections had to be conducted in a neutral political environment in which no party would be advantaged. Provision 14 further indicated that all Cambodians should enjoy the 'same rights, freedoms, and opportunities' to participate in the elections process. ${ }^{113}$ The Charter principle of self-determination was now reintroduced in relative isolation from such state-centric concepts as 'territorial integrity' and 'political independence'. In the Cambodian context, the principle was interpreted more in terms of human-centric values, with the emphasis on political rights and civil liberties. In other words, self-determination was perceived more in relation to its 'internal' dimension, implying a people's right to freely determine their own political future. 


\section{UNTAC deployed}

UN deployment in Cambodia was actually formalised prior to the signing of the Paris Accords. Upon the request of the SNC on 26 August 1991, , $^{114}$ the deployment of a UN Advance Mission in Cambodia (UNAMIC) was authorised by the Security Council. ${ }^{115}$ Its mandate had a powerful inter-state dimension formulated as 'cessation of foreign military assistance', that is, Vietnamese aid. UNAMIC was to assist in maintaining the cease-fire and to liaise with the SNC on the implementation of the Paris Accords. ${ }^{116}$ In January 1992 UNAMIC's mandate was expanded to include an extensive mine clearance programme as well as road and bridge repairs. ${ }^{117}$ The following month came the Secretary-General's detailed operational plan for the actual peacekeeping mission envisaged for Cambodia (UNTAC), ${ }^{118}$ and the Security Council's authorisation of it. ${ }^{119}$ UNTAC would soon absorb UNAMIC.

The Secretary-General's operational plan led to an elaborate mission structure of seven interlinked components: ${ }^{120}$ military, civil administration, ${ }^{121}$ electoral, police, human rights, ${ }^{122}$ repatriation, and rehabilitation. ${ }^{123}$ The operation was designed to proceed in four stages over two years. The 'Preparatory Phase' would be followed by a 'Cantonment and Demobilisation Phase', which, upon successful completion, would in turn give way to the 'Electoral Phase', and eventually the 'Post-Electoral Phase', bringing UNTAC's mandate to an end.

Perhaps the first difficulty UNTAC faced related to repatriation. The UN addressed this issue not only through UNTAC, but also through its expert organ, the UNHCR. There were more than 360,000 Cambodian refugees living along the Thai border. The majority of them preferred to stay in northwest Cambodia - reportedly because of their fear of renewed fighting - from where they could escape to Thailand if need arose. ${ }^{124}$ Faced by this unwillingness to move, the UNHCR had to shift its repatriation policy, and on 20 May 1992 presented more attractive options to refugees, including land, building, cash, employment and family reunification possibilities. ${ }^{125}$ Progress towards maintenance of peace and security required active handling of the socio-economic situation on the ground.

According to the Paris Accords, the four parties had to pursue a phased and balanced process of demobilisation of their military forces. This process was to be completed before the end of voter registration. Phase Two was scheduled to begin on 13 June, but the Khmer Rouge proved to be a major obstacle. It not only committed cease-fire violations, but also refused entry to UNTAC troops in the areas under its control. ${ }^{126}$ Furthermore, it failed to provide information about its troops, equipment and mine fields - all of this on the grounds that Vietnamese forces were still operating in Cambodia. Unless they were totally withdrawn and their non-return ensured, the Khmer Rouge 
would not demobilise, disarm or leave aside security considerations. The other three parties expressed their readiness to begin with the Cantonment Phase. The Secretary-General recommended that as of 13 June 1992 UNTAC should proceed with the second phase regardless of the level of Khmer Rouge non-cooperation. ${ }^{127}$ Not to do so, he argued, would seriously jeopardise the missions' functions, especially the organisation of elections. ${ }^{128}$ This view was endorsed by the Security Council on 12 June 1992. ${ }^{129}$

Meanwhile, both Khmer Rouge non-cooperation and diplomatic attempts to overcome that non-cooperation continued. On 22 June 1992, an international conference was held in Tokyo, at which 33 countries pledged nearly US\$900 million for Cambodia's recovery and an International Committee on the Reconstruction of Cambodia was created. ${ }^{130}$ The conference also attempted to create an atmosphere more conducive to negotiation between the Cambodian parties. Socio-economic conditions were now explicitly underlined as a precondition of peace and security. All factions, except for the Khmer Rouge who maintained that the SNC was not able to exercise its powers, accepted the Tokyo proposals. Phnom Penh, the Khmer Rouge argued, was largely in control of the administrative structure. Ironically, it was not so much the UN's presence in Cambodia that the Khmer Rouge were now criticising as the lack of active involvement on the UN's part.

\section{International determination to settle the internal conflict}

The decision to proceed with Phase Two soon necessitated a more fundamental decision on whether or not the operation should be suspended altogether until all four factions complied with the Paris Accords. ${ }^{131}$ The decision became increasingly unavoidable, as the lack of Khmer Rouge cooperation was causing comparable and growing hesitation on the part of the other factions. According to the UN plan, Phase Two had to be completed by 11 July 1992, but one day before the envisaged deadline only 13,500 out of a total of 200,000 Cambodian troops had been cantoned. ${ }^{132}$

September 1992 saw intensive diplomatic efforts to overcome the difficulties. Australia presented a paper underlining how the international community should now proceed. ${ }^{133}$ In a statement the Security Council strongly reaffirmed its commitment to the principles of the Paris Accords. ${ }^{134}$ On 30 September 1992, the KPNLF specified a set of conditions, which, once met, would remove the basis of any further Khmer Rouge non-cooperation. These moves culminated in SC Resolution 783 of 13 October 1992, which declared that the Cambodian election process would proceed as planned. UNTAC's much-contested Electoral Law had already been adopted on 5 August. ${ }^{135}$ Despite the opposition of internal parties, the international actors 
were of the view that the rules of election should be determined by the UN, thereby re-confirming its authority.

In October and November, a series of unsuccessful diplomatic efforts were made by Thailand and Japan on the one hand, ${ }^{136}$ and France and Indonesia on the other. ${ }^{137}$ In his report of 15 November 1992, the Secretary-General informed the Security Council that Khmer Rouge cooperation had still not been ensured. By that time sporadic fighting was taking place between the Khmer Rouge and Phnom Penh forces, with the former launching assaults on ethnic Vietnamese, and even UNTAC personnel coming under attack. ${ }^{138}$ On 30 November 1992, the Security Council resolved that elections for a constituent assembly would be held no later than May 1993. It insisted that the Khmer Rouge were not being 'excluded' from the election process - a longstanding Chinese concern. It was entirely up to the Khmer Rouge to decide whether or not they would participate. The rules of the game were already set and could not be changed. In line with this tougher stance, the Security Council was now intent on tightening the economic sanctions imposed on the Khmer Rouge. ${ }^{139}$

The Khmer Rouge problem aside, practically all the major parties 'engaged in a certain degree of misleading propaganda and political coercion during the registration/campaign period'. ${ }^{140}$ In December 1992, the tension in the country increased, as cease-fire violations became more frequent. Apart from inter-factional clashes, Khmer Rouge forces detained UNTAC personnel on more than one occasion. The Khmer Rouge held that such incidents were provoked by UNTAC. In a letter to the Secretary-General, they argued that in all such instances, it was UNTAC personnel that had entered the zones under Khmer Rouge control without first informing them. ${ }^{141}$ This view had a striking resemblance to Katanga's approach during the Congo crisis. However, unlike Hammarskjöld's strict adherence to the norm which required the parties' continuous consent, UNTAC was implementing a mandate that was based on a single all-encompassing consent.

By February 1993, it was Phnom Penh's turn to place obstacles in the path of UNTAC. Hun Sen's decision to initiate a military offensive against Khmer Rouge forces ${ }^{142}$ caused growing dissatisfaction on the part of all parties, though their reasons differed. ${ }^{143}$ On 4 January 1993, Sihanouk informed Akashi that the violent campaign against his party obliged him to cease all further cooperation with UNTAC. Hun Sen, for his part, demanded Chapter VII enforcement against the Khmer Rouge. While the SecretaryGeneral was eventually able to appease both parties, they remained highly sceptical of the UN's role.

The electoral campaign in Cambodia began on 7 April 1993. The Khmer Rouge, having announced that it would not participate in the election, continued to charge the Vietnamese with aggression. The Phnom Penh 
faction used the state administration under its control to gain an advantage over FUNCINPEC and other parties. Boutros-Ghali points out that 'strong intervention by UNTAC' had been necessary to secure the release by the Phnom Penh faction of FUNCINPEC's broadcasting equipment. ${ }^{144}$ While dealing with these difficult challenges to its authority, UNTAC, and especially Radio UNTAC, remained at the forefront throughout the campaign process.

Between April and mid-May 1993, violence intensified, with members of all factions, as well as several UNTAC personnel, being injured or killed. ${ }^{145}$ Most of the victims, however, were of Vietnamese descent. By the end of April 1993, more than 21,000 ethnic Vietnamese had become refugees or displaced persons, including second- and third-generation Cambodian residents. Paradoxically, as of 30 March 1993, with the closure of the last refugee camp at the Thai border, UNTAC had successfully completed its original repatriation programme, ${ }^{146}$ only to see a different refugee problem emerge, which it was either unable or unwilling to address. In BoutrosGhali's words, 'the issue of the status of ethnic Vietnamese resident in Cambodia had not been provided for in the Paris Accords, and some within UNTAC's leadership were inclined to think of the situation as an internal security issue for Cambodian authorities to resolve. ${ }^{, 147}$ In other words despite the UN's clear involvement in an internal conflict in Cambodia, there were limitations or reservations as to the extent of such involvement. The overarching concern over the maintenance of international peace and security resurfaced now and again.

For election purposes, Cambodia was divided by UNTAC into three types of security zone: low-, medium- and high-risk zones. In Boutros-Ghali's words, 'the Cambodian parties had primary responsibility for maintaining the security of the zones they controlled'. ${ }^{148}$ This was the limit of the UN's 'protectorate', normatively expected yet practically unsustainable. UNTAC even agreed to the request that some of the weapons cantoned by UNTAC be returned to the relevant factions. These, then, were the circumstances in which elections would be conducted.

The elections took place between 23 and 28 May 1993. Some 90 per cent of the nearly 4.2 million registered voters cast their votes. Khmer Rouge's boycott and threats proved highly unsuccessful. On 29 May 1993, the Secretary-General endorsed his Special Representative's assessment that the conduct of the elections had been free and fair. ${ }^{149}$ The final vote tally was released on 10 June 1993. FUNCINPEC won 45.5 per cent of the votes and became the first party. Thereupon Phnom Penh raised accusations of irregularities and fraud in the elections, in which it had obtained 38 per cent of the votes. ${ }^{150}$ The BLDP had come in third with less than 4 per cent of all votes.

On 16 June Sihanouk established an Interim Joint Administration, with 
Prince Ranarriddh and Hun Sen as co-chairmen of the Council of Ministers. The Security Council restated that UNTAC's mandate would end upon the creation of a new Cambodian Government. ${ }^{151}$ On 24 September UNTAC's mandate formally ended, signifying 'Cambodia's democratic transition to Neo-authoritarianism'. ${ }^{152}$

\section{Concluding observations}

Quite apart from the triangular geostrategic rivalry between China, the Soviet Union and the United States, regional tensions between Vietnam, China and ASEAN as well as the ideological intra-Khmer and ethnic Khmer-Vietnamese frictions had created within Cambodia a complex blend of mistrust and animosity. The normative basis of the UN's response to the Cambodia conflict emerged from a painfully slow process of informal bilateral and formal multilateral negotiations over more than a decade, in which the predominant concern was to accommodate the strategic interests of the actors involved.

The UN was able to assert its authority vis-à-vis Cambodia only when the key antagonists, though still deeply suspicious of each other, were finally reconciled, in the wake of a structural change in world politics, to putting an end to a protracted conflict that had consumed a great deal of resources, time and effort with little corresponding benefit. The end of the Cold War was presumably an important catalyst for this sequence of events. The UN suggested itself as a well placed mechanism through which these competing interests could be accommodated and it was given considerable leeway to exercise a relatively independent authority - in ways that might well set an irreversible precedent - in a conflict where diverse but powerful local, regional and global antagonisms had hitherto proved mutually reinforcing. This, of course, had a price tag attached to it. The principle of non-intervention, understood as absolute 'respect' for external state sovereignty, was effectively superseded.

As with the other cases we have examined, maintenance of international peace and security, with particular reference to regional stability, remained the primary international concern both before and during the Cambodia operation. The value attached to sovereignty manifested itself largely in the preoccupation with the promotion of its internal aspect which, in a sense, had to go hand in hand with internal self-determination as well as with protection and promotion of human rights in general. These principles were incorporated into the composite notion of 'good governance'. The international community was also concerned with issues of socio-economic development, to a much higher degree than in any of the previous cases under consideration. Several UN and non-UN development projects were set in motion in tandem with the peacekeeping mission. Indeed, the socio-economic develop- 
ment objective was attached directly to the peacekeeping mandate under the rubric of 'reconstruction'.

A crucial factor in the UN's emphasis on human rights was the persistent moral pressure exerted by civil society organisations after the Khmer Rouge atrocities became known in the mid- to late 1970s. Arguably just as important was the significant overlap between the self-serving application of human rights discourse by western governments and three key non-western players, Moscow, Hanoi and Phnom Penh, who defended their position, partly with western 'audiences' in mind, as the legitimate and morally appropriate response to Khmer Rouge atrocities. On the other hand, the increasing NGO involvement in relief and reconstruction efforts throughout the 1980s brought along an emphasis on Cambodia's development.

Compared with the previous cases we have surveyed, Cambodia conveys a sense of 'comprehensiveness' in several respects. When authorised it became the largest UN mission ever deployed. It assumed multiple and complex tasks, involving extensive participation in the day-to-day running of the country. The evolution of the UNTAC concept was itself based on comprehensiveness, in the sense that the Jakarta Informal Meetings and the Paris process involved a great many interested actors and active participants. But what exactly does such comprehensiveness signify for the UN's role, beyond changing objectives and enhanced authority? Is it indicative of a new normative trend? If so, what is the underlying logic of this trend? We will now reflect on these questions.

\section{NOTES}

1 The estimated population of Cambodia in 1990 was 8,570,000: see IMF, International Financial Statistics on CD-ROM (Washington DC: series code 6870). The ratio of UNTAC's largest authorised strength to the local population was 25/10,000.

2 D. Sagar, 'Historical survey', in M. Wright (ed.), Cambodia: A Matter of Survival (Essex: Longman, 1989), p. 11.

3 Sihanouk, arguably the most colourful personality in post-War Cambodian politics, served Cambodia in different capacities: King, Prime Minister, Chief of State, and again King. Until 1963, Sihanouk adopted a policy of neutralism against the two blocs. Then, until 1967, he adopted a pro-Chinese and North Vietnamese line. At the height of the Chinese Cultural Revolution, he went back to neutrality. From the late 1970s, he became increasingly pro-Western: see Morris, Why Vietnam Invaded Cambodia, p. 46.

4 See Sagar, 'Historical survey', p. 23.

5 After he was removed from power, first, by the pro-American coup, and then by the Khmer Rouge, Sihanouk maintained good relations with China (and North Korea), which, although largely symbolic, would prove crucial for the international efforts towards a Cambodian settlement in the 1990s: see H. C. Mehta and J. B. Mehta, Hun Sen: Strongman of Cambodia (Singapore: Graham Brash, 1999), pp. 162-3.

6 Among the victims were Cambodia's Buddhist monks and ethnic minorities such as the Vietnamese, Thai and Cham Muslims: see Mehta and Mehta, Hun Sen, p. 258. 


\section{The UN in the Cambodia conflict}

7 While up to 20 per cent of this number is estimated to have resulted from outright executions, the rest is attributed to the conditions created by the Khmer Rouge regime, including starvation and deportation: see J. F. Metzl, Western Responses to Human Rights Abuses in Cambodia, 1975-1980 (Houndmills: Macmillan, 1996), p. xviii.

8 Former Thai Prime Minister Kraivichien reportedly accused Cambodia of intruding into his country 400 times between January and August 1977: see S. Peou, Conflict Naturalization in the Cambodia War: From Battlefield to Ballot-box (New York: Oxford University Press, 1997), p. 23.

9 See D. Roberts, 'More honoured in the breech: consent and impartiality in the Cambodian peacekeeping operation', International Peacekeeping, 4:1 (Spring 1997), 8.

10 Mehta and Mehta, Hun Sen, p. 258.

11 According to US estimates, the number of Vietnamese troops deployed in Cambodia reached 224,000 in 1979. By 1988, the number was reduced to about 100,000: see K. Berry, Cambodia - From Red to Blue: Australia's Initiative for Peace (Canberra: Allen \& Unwin, 1997), p. 10.

12 Morris, Why Vietnam Invaded Cambodia, p. 16.

13 Morris, Why Vietnam Invaded Cambodia, pp. 161-6.

14 Morris, Why Vietnam Invaded Cambodia, pp. 170-96.

15 Morris, Why Vietnam Invaded Cambodia, pp. 209-15.

16 In April 1989, the regime would be renamed the State of Cambodia - SOC. This new regime would last de jure until the formation of the Supreme National Council in 1990, and de facto until after the Cambodian elections of May 1993.

17 Despite their uneasy relationship with Thailand, the Khmer Rouge had established diplomatic relations with all ASEAN members but Indonesia. Upon increasing tension with Vietnam, the Khmer Rouge further 'courted' ASEAN. By August 1978, the Khmer Rouge ensured diplomatic relations with Indonesia at the ambassadorial level: see Morris, Why Vietnam Invaded Cambodia, pp. 83-4.

18 Ratner, The New Peacekeeping, p. 142.

19 M. Alagappa, 'Regionalism and the quest for security: ASEAN and the Cambodian conflict', Australian Journal of International Affairs, 47:2 (October 1993), 199; and Mehta and Mehta, Hun Sen, p. 78.

20 See D. Chandler, 'Three visions of politics in Cambodia', in M. W. Doyle, I. Johnstone and R. C. Orr (eds), Keeping the Peace: Multidimensional UN Operations in Cambodia and El Salvador (Cambridge: Cambridge University Press, 1997), p. 49.

21 S. Lithgow, 'Cambodia', in K. Clements and R. Ward (eds), Building International Community: Cooperating for Peace Case Studies (St. Leonards: Allen \& Unwin, 1994), p. 29.

22 See Alagappa, 'Regionalism and the quest for security', p. 196.

23 For an excellent account of the initial formation of western public opinion on the issue, see Metzl, Western Responses, especially pp. 46-65.

24 Ratner, The New Peacekeeping, p. 141.

25 J. P. de Cuéllar, Pilgrimage for Peace: A Secretary-General's Memoir (Basingstoke: Macmillan, 1997), p. 448.

26 See N. Sihanouk, War and Hope: The Case for Cambodia (London: Sidgwick \& Jackson, 1980), p. 137.

27 Meanwhile, in March 1984, Australia and Vietnam worked out an agreement of principle consisting of five points: Vietnam's withdrawal from Cambodia; elimination of the Pol Pot group and creation of a safety zone along the Thai-Cambodian border; Cambodia's self-determination by elections; guarantee of security for the Chinese-Vietnamese, Chinese-Laotian and Thai-Laotian borders; and international 


\section{The UN, intra-state peacekeeping and normative change}

supervision of these provisions. ASEAN responded by arguing that the Cambodian conflict was between Vietnam and Cambodia, not ASEAN. Rafeeuddin Ahmed, the Special Representative of the Secretary-General, pointed out to Vietnam that ASEAN could not be expected to discuss the Chinese-Vietnamese and Chinese-Laotian borders with Vietnam; see de Cuéllar, Pilgrimage for Peace, pp. 450-1.

28 For a very comprehensive review, see Berry, Cambodia.

29 Mehta and Mehta, Hun Sen, p. 102.

30 Alagappa, 'Regionalism and the quest for security', p. 200.

31 Peou, Conflict Naturalization in the Cambodia War, p. 33.

32 And to a lesser, though by no means unimportant, extent the United States.

33 The UN Commission of Human Rights, for instance, had been discussing the matter since the late 1970s, albeit with a remarkable ineffectiveness.

34 On 22 October 1988, Khieu Samphan, the Khmer Rouge spokesman, indicated his support for the idea.

35 Provision 11 in the Khmer Rouge peace proposal of 22 November 1988.

36 See de Cuéllar, Pilgrimage for Peace, p. 455.

37 The statement issued at the end of the meeting emphasised both the "withdrawal of Vietnamese forces within the context of an overall solution' and the 'prevention of the recurrence of genocidal policies and practices of the Pol Pot regime': see Jakarta Informal Meeting 2 'Consensus Statement', issued on 21 February by Indonesian Foreign Minister Ali Alatas, reproduced in McMillen (ed.), Conflict Resolution in Kampuchea, pp. 146-51.

38 Berry, Cambodia, pp. 12-13.

39 ASEAN foreign ministers, in contrast, called for a comprehensive settlement and effective UN supervision: see 'ASEAN Foreign Ministers' Call for a Comprehensive Political Settlement of the Kampuchean Problem' of 3 July 1989, available online at www.asean.org/general/ads1989/kampuchean_89.htm (13 April 2001).

40 According to the wording of the final document produced at the conclusion of the Second Paris Conference on Cambodia (The Final Act of the Paris Conference of 23 October 1991; see A/46/608-S/23177 of 30 October 1991), there was only one Paris Conference on Cambodia, and that conference was held in two sessions, the first from 30 July to 30 August 1989, and the second from 21 to 23 October 1991. In contrast to this official presentation of the events, here we will refer to two separate Paris Conferences on Cambodia just to make it clear that originally the conference was not contemplated in two sessions, and the second Conference may not have taken place at all, had circumstances not changed.

41 A. Acharya et al. (eds), Cambodia - The 1989 Paris Peace Conference: Background Analysis and Documents (Toronto: Centre for International and Strategic Studies, York University, 1991), pp. 125, 129 cited in M. Brown and J. J. Zasloff, Cambodia Confounds the Peacemakers, 1979-1998 (Ithaca: Cornell University Press, 1998), p. 54.

42 De Cuéllar, Pilgrimage for Peace, p. 461.

43 Brown and Zasloff, Cambodia Confounds the Peacemakers, p. 56.

44 See de Cuéllar, Pilgrimage for Peace, pp. 460-2.

45 However, Prince Sihanouk and China would maintain in due course that more than 100,000 Vietnamese soldiers remained under disguise in Cambodia: see Brown and Zasloff, Cambodia Confounds the Peacemakers, p. 58.

46 GA Resolution 44/22 of 16 November 1989.

47 Evans' plan had been influenced by Stephen Solarz, the Chairman of the US House of Representatives Subcommittee on Southeast Asia, who had developed the idea of a UN 'interim administration': see G. Evans, 'Achieving Peace in Cambodia'. 


\section{The UN in the Cambodia conflict}

48 The so-called (from the colour of its binding) 'Red Book' consisted of one overview paper, six working papers, and three supplementary papers: see Cambodia: An Australian Peace Proposal (Canberra: Department of Foreign Affairs and Trade, Commonwealth of Australia, Working Papers for the Informal Meeting on Cambodia, Jakarta, 26-28 February 1990).

49 Overview Paper, para. 2.

50 Overview Paper, para. 4.

51 Working Paper 1, para. 23; see also Working Paper 2, paras 27, 40.

52 The 'Sources of Authority for Government Structure' were summarised in 5 steps; see Working Paper 1, para. 10.

53 On 15 January and 16 March 1979, for instance, the Soviet Union had vetoed two draft resolutions condemning the Vietnamese intervention.

54 Brown and Zasloff, Cambodia Confounds the Peacemakers, p. 61.

55 Evans cited in F. Frost, The Peace Process in Cambodia: Issues and Prospects (Queensland: Centre for the Study of Australia-Asia Relations, Australia-Asia Papers No. 69, October 1993), pp. 5, 51.

56 See Working Paper 2, paras 27-8.

57 British Foreign Secretary Hurd stated that his Government welcomed the Australian proposal. The Permanent Five had agreed on the principles which should underpin a settlement. These included 'an enhanced role for the United Nations, the modalities of a peace-keeping effort in Cambodia, and the administrative structure during the interim period of United Nations involvement': see UK House of Commons, Hansard Debates, 26 March 1990, cols 29-30.

58 See Peou, Conflict Naturalization in the Cambodia War, pp. 41-2.

59 S/21087 dated 18 January 1990.

60 See S/21689 of 31 August 1990. By Resolution 668 of 20 September 1990, the Security Council endorsed the Framework Agreement, encouraged the continuing efforts of the Permanent Five, and conferred upon the SNC formal legitimacy.

61 The most important among these were the meetings of 11-12 February, 12-13 March, 25-26 May and 16-17 July 1990.

62 Yet it continued to insist on giving the SNC 'a status that would at least imply the dismantling of the Phnom Penh regime': de Cuéllar, Pilgrimage for Peace, p. 466.

$63 \mathrm{~S} / 21087$, para. 4.

$64 \mathrm{~S} / 21087$, para. 6 .

$65 \mathrm{~S} / 21087$, para. 11.

$66 \mathrm{~S} / 21087$, para. 8 .

$67 \mathrm{~S} / 21087$, para. 10.

$68 \mathrm{~S} / 21087$, para. 9.

69 De Cuéllar, Pilgrimage for Peace, p. 465.

70 De Cuéllar, Pilgrimage for Peace, pp. 464-5.

71 De Cuéllar, Pilgrimage for Peace, p. 470.

72 For the communiqué, see S/21985 of 6 December 1990.

73 Soon after, ASEAN would 'fully support an enhanced role for the United Nations in Cambodia' and call for a 'Supreme National Council representing all shades of political opinion that could administer Cambodia in the interim period through existing administrative structures in conjunction with the United Nations': see Joint Statement of the ASEAN Foreign Ministers on the Cambodian Problem of 23 July 1990, available online at www.aseansec.org/general/ads1990/afm_cam90.htm (13 April 2001).

74 According to the adopted formula, 6 members were appointed from the Phnom Penh Government, and 2 members each from FUNCINPEC, the KPNLF and the PDK. 


\section{The UN, intra-state peacekeeping and normative change}

75 Important meetings included those of 21-22 December 1990 (Paris), 24-26 June 1991 (Pattaya), 16-17 July 1991 (Beijing) and 26-29 August 1991 (Pattaya).

76 During the SNC meeting of 24-26 June 1991, all parties agreed that the UN should supervise the cease-fire. However, Phnom Penh still refused a strong UN military presence in Cambodia: see Peou, Conflict Naturalization in the Cambodia War, pp. 44-5.

77 This time Yugoslavia had replaced Zimbabwe in its capacity as the chairman of the NAM.

78 The full titles are, respectively, the Final Act of the Paris Conference on Cambodia; the Agreement on a Comprehensive Political Settlement of the Cambodian Conflict; the Agreement Concerning the Sovereignty, Independence, Territorial Integrity and Inviolability, Neutrality, and National Unity of Cambodia; and the Declaration on the Rehabilitation and Reconstruction of Cambodia.

79 Actually this is precisely what would happen at different stages of the UNTAC operation.

80 Agreement on Political Settlement, para. 28.2.

81 Agreement on Political Settlement, para. 6.

82 In his 'Cambodia: our experience with the United Nations', Pacifica Review, 7:2 (Oct/Nov. 1995), 62.

83 Annex 1 to the Agreement on Political Settlement, Section B, para. 1.

84 SC Resolution 745 of 28 February 1992; operative para. 1.

85 After the signature of the Paris Accords, as Ratner points out, most states held that Cambodia was the UN's problem, that is the Secretary-General's problem: see Ratner, The New Peacekeeping, p. 161.

86 Agreement on Political Settlement, preambular paras 1 and 10.

87 Telegram of the Secretary of State to all East Asian and Pacific Diplomatic Posts (June 1976) cited in Metzl, Western Responses, p. 62 n. 154.

88 Metzl, Western Responses, p. 95.

89 Metzl, Western Responses, p. 179.

90 For an overview of World Vision's activities from 1970 to 1996, see J. Sarma et al., 'World Vision in conflict and peace: a perspective from Cambodia', Pacifica Review, 8:2 (Nov/Dec. 1996), 69-79.

91 For an overview, see J. Bennett et al., Meeting the Needs: NGO Coordination in Practice (London: Earthscan Publications, 1995), pp. 168-73.

92 See Bennett et al., Meeting the Needs, pp. 175-6.

93 Bennett et al., Meeting the Needs, pp. 177-9.

94 These included such well known organisations as Community Aid Abroad, Oxfam, and the Quakers.

95 E. Mysliwiec, Punishing the Poor: The International Isolation of Kampuchea (Oxford: Oxfam, 1988), p. ix.

96 Mysliwiec, Punishing the Poor, p. 52.

97 S/PV.2108 of 11 January 1979, p. 13.

98 E/CN.4SR.1469 and E/CN.4/SR.1473 cited in Metzl, Western Responses, p. 96 n. 197.

99 The change in the attitude of the socialist bloc is noted by Sihanouk in his War and Hope, p. 104.

100 De Cuéllar, Pilgrimage for Peace, pp. 452-4.

101 See GA Resolution 44/22 of 16 November 1989 and SC Resolution 745 of 28 February 1992.

102 S/PV.2108 of 11 January 1979, p. 2.

103 A phrase that alludes to enforcement measures under Chapter VII.

104 S/21689 of 31 August 1990, para. 36. 


\section{The UN in the Cambodia conflict}

105 Congressional Record of the United States, 25 April 1978, p. 11337 cited in Metzl, Western Responses, p. 113 n. 120.

106 It was a decade later, during the Bush administration, that the United States finally withdrew recognition from the CGDK, though without extending recognition to the Phnom Penh Government: see Alagappa, 'Regionalism and the quest for security', pp. 201-2.

107 De Cuéllar, Pilgrimage for Peace, pp. 454-5.

108 De Cuéllar, Pilgrimage for Peace, p. 454.

109 Framework Document, Section 4, para. 24.

110 A/46/61-S/22059 dated 11 January 1991; a point noted in Peou, Conflict Naturalization in the Cambodia War, pp. 150-1.

111 Para. 10.

$112 \mathrm{~S} / 21087$ of 18 January 1990.

113 Although no direct relationship was established between the envisaged UN mission and the principles by which a settlement should be reached, it is possible to argue that the Permanent Five document did embody an understanding of UN impartiality, where the contents were in need of further elaboration. What would 'domination' by any one party entail? What were the rights, freedoms and opportunities that all parties were supposed to enjoy under a guiding principle of 'sameness'?

114 See A/46/494-S/23066 of 24 September 1991.

115 SC Resolution 717 of 16 October 1991.

116 UNAMIC's deployment began on 9 November 1991; see Report of the SecretaryGeneral on UNAMIC, S/23218 of 14 November 1991.

117 SC Resolution 728 of 8 January 1992.

118 S/23613 of 19 February 1992.

119 SC Resolution 745 of 28 February 1992.

120 The number of international and Cambodian personnel required to accomplish the tasks would be 21,000 and 56,000 respectively: see Report of the Secretary-General, S/23613 of 19 February 1992.

121 The civil administration component had the authority to issue 'binding directives': see M. W. Doyle, 'Authority and elections in Cambodia', in Doyle, Johnstone and Orr (eds), Keeping the Peace, p. 137.

122 Doyle observes that, 'Never before had a UN peacekeeping operation assumed so intrusive and authoritative a mandate to implement universal human rights.' See Doyle, 'Authority and elections in Cambodia', p. 146.

123 Several studies, which concentrate usually on the operational aspects of UNTAC, find it useful to offer separate reviews for each of these components. Examples include Brown and Zasloff, Cambodia Confounds the Peacemakers, pp. 95-129 and Ratner, The New Peacekeeping, pp. 169-85. For our purposes there is no need to provide such an assessment.

124 By the end of April 1992, not more than 6,000 persons had returned to Cambodia. In the subsequent three months, the number of returning refugees reached 130,000.

125 See United Nations, The United Nations and Cambodia, 1991-1995 (New York: UNDPI, 1995), pp. 19-20.

126 The Secretary-General reported that on one occasion even his Special Representative and the Force Commander had been denied entry: see United Nations, The United Nations and Cambodia, p. 17.

127 See S/24090 of 12 June 1992.

128 One consideration was that the elections should be held before Cambodia's rainy season. 


\section{The UN, intra-state peacekeeping and normative change}

129 See S/24091 of 12 June 1992.

130 The participants were the Permanent Five, all nine members of today's ASEAN, all but two members of today's EU (Greece and Luxembourg were absent), Australia, Canada, India, Japan, New Zealand, Norway, South Korea, Switzerland, the European Community (in its collective capacity) and the Special Representative of the SecretaryGeneral. The biggest donors would be Japan with US\$200 million and the United States with US\$135 million.

131 Meanwhile, by 15 July the civil administration component had established offices in all 21 provinces. By September 1992, UNTAC was almost fully established throughout Cambodia. In the area of finance, for instance, as of early September 1992, financial controllers were present in each of the ministries, in the National Bank of Cambodia, and in Phnom Penh's provincial administrations: see United Nations, The United Nations and Cambodia, p. 22.

132 United Nations, The United Nations and Cambodia, p. 24; see also S/PV.3099 of 21 July 1992, p. 18.

133 Australian paper entitled 'Cambodia: next steps' (16 September 1992).

134 S/24587 dated 25 September 1992.

135 The first electoral law was drafted in April 1992. The CGDK partners, with an antiVietnamese Khmer sentiment, strongly opposed this draft, claiming that it gave 'Vietnamese' suffrage. However, the rewritten draft too did not meet these factions' notion that political participation should be based on ethnic criteria: see Roberts, 'More honoured in the breech', p. 9.

136 The Security Council, in its Resolution 783, had requested these two countries to continue their unrelenting diplomatic efforts.

137 The Secretary-General requested the Co-Chairmen of the Paris Conference to undertake consultations.

138 Boutros-Ghali's depiction of the political climate in November 1992 is noteworthy: see United Nations, The United Nations and Cambodia, p. 26, para. 62.

139 See United Nations, The United Nations and Cambodia, p. 27, para. 65.

140 United Nations, The United Nations and Cambodia, p. 29, para. 70. For a concise analysis, see K. Frieson, 'The politics of getting the vote in Cambodia', in S. Heder and J. Ledgerwood (eds), Propaganda, Politics, and Violence in Cambodia: Democratic Transition under United Nations Peace-keeping (New York: M. E. Sharpe, 1996), pp. 183-207. Between 5 October 1992 and 31 January 1993, during the period of voter registration, about 4.6 million Cambodians registered to vote. This figure represented nearly all of the eligible voters outside of Khmer Rouge-controlled areas. UNTAC was largely denied access to the areas under Khmer Rouge control. However, according to estimates, those areas did not contain more than 5 per cent of the total Cambodian population anyway: see United Nations, The United Nations and Cambodia, p. 29, paras 69-70.

141 Letter dated 20 December 1992 from Khieu Samphan to the Secretary-General: see United Nations, The United Nations and Cambodia, pp. 246-8.

142 See United Nations, The United Nations and Cambodia, p. 34, para. 80. In fact, two main streams of violence were detectable: the first by Phnom Penh against FUNCINPEC, the second by the Khmer Rouge against the ethnic Vietnamese: see M. Plunkett, 'The establishment of the rule of law in post-conflict peacekeeping', in Smith (ed.), International Peacekeeping, p. 71.

143 See United Nations, The United Nations and Cambodia, pp. 35-6 (para. 87), and 249-51.

144 United Nations, The United Nations and Cambodia, p. 39, para. 93.

145 At the end of the mission, total fatalities of UNTAC were 78: see UN webpage at www.un.org/Depts/DPKO/Missions/untac.htm (15 September 1997). 
146 All nine refugee camps at the Thai border were finally closed.

147 United Nations, The United Nations and Cambodia, p. 42, para. 99; emphasis added.

148 United Nations, The United Nations and Cambodia, p. 43, para. 104.

149 S/25879 dated 2 June 1993.

150 S/25879 dated 2 June 1993. Phnom Penh's allegations were practically ignored by UNTAC: see the Report of the Secretary-General, S/25913 of 10 June 1993, especially paras 9-12.

151 SC Resolution 860 of 27 August 1993.

152 S. Heder cited in W. Shawcross, Deliver Us from Evil: Warlords \& Peacekeepers in a World of Endless Conflict (London: Bloomsbury, 2000), p. 184. 